\title{
Etkinliklerle çocuk edebiyatı yapıtlarının Türkçe öğretiminde kullanılması
}

\section{Tuncay TÜRKBEN 1}

\begin{abstract}
APA: Türkben, T. (2019). Etkinliklerle çocuk edebiyatı yapıtlarının Türkçe öğretiminde kullanılması.
\end{abstract} RumeliDE Dil ve Edebiyat Araşttrmaları Dergisi, (16), 160-179. DOI: 10.2900o/rumelide.616917

\section{$\ddot{\mathbf{O z}}$}

Türkçe öğretimi ile anlama ve anlatma becerileri gelişmiş, dil bilinci ve duyarlılığına sahip, okuma kültürü edinmiş, millî ve evrensel değerleri içselleştirmiş, düşünen duyarlı bireylerin yetiştirilmesi hedeflenmektedir. Türkçe öğretimi ile yalnız dilsel beceriler değil, düşünme, anlama, sıralama, sinıflama, sorgulama, ilişki kurma, eleştirme, tahmin etme, analiz-sentez yapma, değerlendirme gibi zihinsel becerilerin geliştirilmesi de hedeflenmektedir. Bu becerilerin kazandırılmasında onların ilgi, gereksinim ve dil evrenlerine uygun, Türkçenin anlatım olanaklarının yansıtıldığı metinlerin yeri ve önemi büyüktür. Bu nedenle öğrenciler, ilköğretim birinci sınıftan başlayarak, Türkçenin anlatım gücünü yansıtan, onların dil gelişimlerine ve gereksinimlerine uygun ürünlerle karşılaştırılmalıdır. Ana dili öğretimi bilgiden çok beceri kazandırmayı amaçladığı için hedeflenen beceri ve kazanımların gerçekleştirilmesinde etkinliklerden yararlanılmaktadır. Dört temel dil becerisine yönelik hazırlanacak etkinliklerin bütünsellik içerisinde geliştirilmesi ve öğrencilerin bu becerileri kullanabilecekleri, sınayabilecekleri ortamlar oluşturulmalıdır. Becerilerin tümünün bir denge içinde geliştirilmesi gerekir. Hazırlanan etkinlikler, öğrenci tarafından metnin anlaşılmasını, yorumlanmasını; metinden sonuçlar çıkarıp bu sonuçları yaşamında kullanabilmesini sağlamalıdır. Bu çalışmanın amacı, Türkçe Dersi Öğretim Programı’nda öğrencilere kazandırılmaya çalışılan temel dil beceri alanlarında hedeflenen amaç ve kazanımları gerçekleştirmeye yönelik çocuk edebiyatı metinlerinden hareketle etkinlik oluşturmaktır. Çocuk edebiyatı metinleri doğrultusunda etkinlik tasarlamayı amaçlayan bu çalışmada, nitel araştırma yöntemlerinden belgesel tarama (doküman incelemesi) kullanılmıştır. Belgesel tarama, var olan kayıt ve belgelerden veri toplama tekniğidir. Bu çalışmada, dil becerilerini geliştirmeye yönelik uygulama ve etkinlik örneklerine yer verilmiştir.

Anahtar kelimeler: Türkçe öğretimi, temel dil becerileri, çocuk edebiyatı yapıtları, metin, etkinlik.

\section{Use of children's literature works in Turkish teaching with activities}

\begin{abstract}
It is aimed to educate individuals who have developed comprehension and expression skills with Turkish education, have language awareness and sensitivity, have acquired a reading culture, internalize national and universal values and are sensitive to thinking. It is also aimed to develop mental skills such as thinking, understanding, sorting, classifying, questioning, establishing relationships, criticizing, estimating, analyzing and synthesizing, and evaluating not only linguistic skills but also linguistic skills. In order to gain these skills, the place and importance of texts which are suitable for their interests, needs and language universes, where the expression possibilities of Turkish are reflected. For this reason, students should compare with products that reflect their language development and requirements, starting from the first grade of Primary School. Since
\end{abstract}

1 Dr. Öğr. Üyesi, Aksaray Üniversitesi, Eğitim Fakültesi, Türkçe ve Sosyal Bilimler Eğitimi, Türkçe Eğitimi ABD (Aksaray, Türkiye), tuncayturkben57@gmail.com, ORCID ID: 0000-0003-0167-4173 [Makale kaylt tarihi: 24.05.2019-kabul tarihi: 16.09.2019; DOI: 10.29000/rumelide.616917] 
teaching mother tongue aims to gain more skill than knowledge, activities are used in realization of targeted skills and acquisitions. Development of the activities for four basic language skills should be integrated and the environments where students can use and test these skills should be established. All of the skills need to be developed in a balance. The activities should enable the student to understand, interpret the text and draw conclusions from the text and use these results in his / her life. The aim of this study is to develop an activity based on children's literature texts aimed at achieving the targeted goals and achievements in the areas of basic language skills that are tried to be acquired for the students in the Turkish language curriculum. In this study, which aims to design activities in line with child literature texts, documentary screening (document review) was used for qualitative research methods. Documentary screening is the technique of collecting data from existing records and documents. In this study, examples of practices and activities aimed at improving language skills are given.

Keywords: Turkish teaching, basic language skills, children's literature works, text, activity.

\section{Giriş}

Dil, insanın duygu ve düşünce yapısını oluşturan ve biçimlendiren aynı zamanda insanlar arasında anlaşmayı sağlayan en önemli iletişim aracıdır. İnsanların iletişim kurmaları, bilgi edinmeleri, öğrenmeleri ve kendini geliştirmelerinde dilin ayrı bir önemi vardır. Bu nedenle bütün ülkeler eğitim sistemlerinde ana dili öğretimine büyük önem vermektedirler. Ana dili öğretimi, özellikle ilköğretimde bütün derslerin temelini oluşturmaktadır. Ülkemizde anadilimizin temel becerilerini kazandırma sorumluluğunu üstlenen Türkçe öğretimine büyük görevler düşmektedir. "Türkçe öğretiminin öncelikli sorumluluğu, öğrencilerin dinleme, okuma, konuşma ve yazma becerilerini bilimsel bir anlayışla planlı bir biçimde geliştirmek, onlara Türk dilini doğru, bilinçli kullanma duyarlılığı ve alışkanlığı kazandırmaktır." (Sever, 2003: 28). Türkçe derslerinde gerçekleştirilen etkinliklerle de öğrencilerin anlama ve anlatma becerilerinin geliştirilmesi hedeflenmektedir.

Anlama becerisi sadece Türkçe derslerindeki başarıyı değil, tüm derslerde hedeflenen başarıyı doğrudan etkileyen önemli bir yeterlik alanıdır (Göçer, 2017: 171). Anlama becerisi okuma ve dinleme alt becerilerinden oluşmaktadır. Anlamaya dayalı bu beceriler, alıcı beceriler olarak da ifade edilmektedir (Özdemir, 1983: 11; Yangın, 1998: 36). Bu becerilerden okuma, gözlerin yazıyı görüp tanımasından, zihnin anlama çabasından oluşan karmaşık bir etkinliktir (Nas, 2014: 50). Okuma, gerek okulda gerekse yaşamda önemli bir öğrenme alanıdır. Yapılandırmacı yaklaşıma göre ise okuma, bireyin ön bilgileriyle metindeki bilgileri bütünleştirerek yeni anlamlar oluşturduğu aktif bir süreçtir. Okuma süreci, görme algılama, seslendirme, anlama, zihinde yapılandırma gibi göz, ses ve beynin çeşitli işlemlerinden oluşan karmaşık bir süreçtir (Güneş, 2015: 2-3). Dinleme becerisi ise bireyin sesleri, sözleri, konuşmaları, hareketleri işitme ve görme organlarıyla algılaması; zihinsel işlemlere tabi tutarak anlaması etkinliğidir (Güleryüz, 2013: 98). Dinleme, bireyin hayatta ilk kazandığı beceri olmasına rağmen, ihmal edilen bir dil beceri olarak bilinmektedir (Özbay, 2014: 47).

Anlatma becerileri ise konuşma ve yazma becerilerinden oluşmaktadır. Bu beceriler de verici beceriler olarak bilinmektedir. Konuşma becerisi, kişinin kendisini doğrudan ifade ettiği; duygu ve dileklerini başka kimselere doğrudan anlattığı; kendi başına kullanabileceği değil, başkalarıyla paylaşabileceği bir beceridir (Yalçın, 2018: 216). İlköğretimden başlayarak öğrencilere görüp izlediklerini, duygu, düşünce ve tasarladıklarını, sözle, doğru ve amaca uygun olarak anlatma becerisi kazandırma, onlara söz söylemenin kural ve tekniklerini öğretme, öncelikle Türkçe öğretiminin sorumlulukları arasındadır 
(Sever, 2000: 20). Türkçe öğretiminin temel amaçlarından biri de öğrencilerin yazılı anlatım becerilerini geliştirmektir. Yazma ya da yazılı anlatım, zihinde yapılandırılmış duygu, düşünce ve bilgilerin düzenlenerek anlamlı bir yapı oluşturan sembollerle kâğıda veya başka bir yüzeye dökülme işlemidir (Zorbaz, 2014: 109).

Ana dili öğretiminde, belirlenen amaçlara anlama ve anlatma etkinlikleriyle ulaşılırken; bu etkinlikler yazım, noktalama ve dil bilgisi çalışmalarıyla beslenir, bütünleşir (Sever, 2000: 25). "Dil bilgisi çalışmalarında temel anlayış, bilgiyi öğretmek, kuralı belletmek ya da ezberletmek değil, gösterme ve uygulamalarla öğrencilere kuralı sezdirmek, onların kurala ulaşmaları için uygun eğitim ortamını sağlamak olmalıdır." (Sever, Kaya ve Aslan, 2013: 26). Dil bilgisi çalışmalarının anlama ve anlatma etkinlikleriyle birlikte yürütülmesi gerekir. Dil bilgisi etkinlikleri yapılırken metin temelli hareket edilmelidir. Metin çözümleme çalışmaları yapıldıktan sonra dil ile ilgili etkinliklere geçilmelidir.

Anlama ve anlatma becerilerinin öğrencilere kazandırılmasında hedef kitleye uygun nitelikli bir metinlerin kullanılması önemlidir. Türkçe öğretiminin temel aracı metindir. Türkçe öğretiminde, öğrencilerin ilgi, gereksinim ve dil evrenlerine uygun olarak seçilen metinler, onların duygu ve düşünce eğitiminde önemli sorumluluklar üstlenir (Sever, Kaya ve Aslan, 2013: 20). Bu nedenle hedef kitlesi çocuklar olan, çocuk gerçekliğini önceleyen çocuk edebiyatı yapıtları öğrenme öğretme ortamlarında ele alınıp işlenmeli ve çözümlenmelidir.

Çocukların çocuk edebiyatı metinlerine ulaşabilmesi ve anlayıp zevk alması için öncelikle okuma alışkanlığı kazanmaları gerekir. Okuma alışkanlığı kazanabilmeleri için de çocuklara okurken zevk alabilecekleri metinler sunulmalıdır (Uz Erşahin, 2009: 27). Öğrencilerde dil sevgisi ve dil bilincinin uyandırılmasında Türkçe ders kitapları için seçilen okuma parçalarının önemi büyüktür. Bunun için Türkçe ders kitaplarına seçilecek metinlerde ilginç konu ya da olayları içeren, kolay anlaşılır güzel yazılara yer verilmelidir (Kavcar, Oğuzkan ve Sever, 2005: 8). Bu metinler çocukları nitelikli metinlere yönlendirecek ve onlara zamanla okuma kültürü kazandırmada önemli bir rol üstleneceklerdir (Sever, 2013: 19).

Türkçe öğretiminde belirlenen amaçlara ulaşmada çocuklara yönelik sanatçı duyarlılığıyla oluşturulan metinlerin çok uyaranlı eğitim ortamlarında etkili yöntem ve tekniklerle işlenmesine bağlıdır (Hasırcı, 2015). Çünkü eğitim amaçlarının gerçekleşmesi, öğretim-öğretme süreçlerinin etkililiğine, öğretim öğretme süreçlerinin etkililiği ise büyük ölçüde öğretmene ve onun öğretme ortamında gerçekleştirdiklerine bağlıdır (Açıkgöz, 2003: 20).

Türkçe ders kitaplarına seçilecek metinlerin niteliği kadar metinlerle birlikte hazırlanacak temel dil becerilerine yönelik etkinlikler ve bu etkinliklerin etkin yöntem ve tekniklerle işlenmesi de önem arz etmektedir. Karadüze'e (2016: 19) göre dinleme, okuma, konuşma, yazma becerilerine yönelik etkinliklerle, bireylerin kavram dünyası zenginleştirilerek derinlemesine, çok boyutlu düşünmelerine, her seviyede düşünme becerisi kazanmalarına olanak sağlanabilir.

Öğretim sürecinin en önemli ayaklarından birisi etkinlik gerçekleştirmektir. Etkinliklerin öğrenci düzeyine uygun bir şekilde, beceri kazandırmaya, doğrudan doğruya belirlenen hedeflere dönük olması gerekir. Öğretmen, dil becerilerinin geliştirilmesindeki her tür eğitim ortamına çocuk edebiyatı ürünleri ile katkılar sunabilmelidir (Baş, 2014: 487). Temel dil becerilerine yönelik hazırlanacak etkinlikler birbirini bütünleyen bir anlayışla gerçekleştirilmelidir (Sever, Kaya ve Aslan, 2013: 21). Oluşturulan 
etkinliklerin öğrencide eleştirel okuma, eleştirel düşünme becerilerini geliştirecek, Türkçe Dersi Öğretim Programı'nda belirlenen amaç ve kazanımları gerçekleştirecek nitelikte olması gerekir.

\section{Araştırmanın amacı}

Bu çalışmanın amacı, Türkçe Dersi Öğretim Programı'nda belirlenen temel dil beceri alanlarında hedeflenen amaç ve kazanımları gerçekleştirmeye yönelik çocuk edebiyatı metinlerinden hareketle etkinlik oluşturmaktır.

\section{Yöntem}

Çocuk edebiyatı metinleri doğrultusunda etkinlik tasarlamayı amaçlayan bu çalışmada, nitel araştırma yöntemlerinden belgesel tarama (doküman incelemesi) kullanılmıştır. Belgesel tarama, var olan kayıt ve belgelerden veri toplama tekniğidir (Karasar, 2017: 229). Araştırma için alanyazın taranarak kavramsal bir çerçeve oluşturulmuş daha sonra belirlenen metinler için temel dil becerilerine yönelik etkinlikler oluşturulmuştur.

Çocuk edebiyatı yapıtlarının Türkçe öğretiminde etkinlik temelli bir anlayışla ele alınması, Türkçe öğretiminin niteliğini artıracaktır. Bu doğrultuda öncelikle Türkçe öğretiminde kullanılabilecek yapıtlar belirlenmiştir. Bu yapitlar arasından, uzman görüşü doğrultusunda bir bilgilendirici, bir hikâye edici ve bir şiir metni çalışmada kullanılmak üzere belirlenmiştir. Daha sonra alan yazın taraması sonucu bu etkinliklerin tasarlanmasına geçilmiştir. Bu etkinliklerin tasarlanmasında birçok çalışma kaynaklık etmiştir (Baş, 2015; Göçer, 2017; Güleryüz, 2013, Sever, Kaya ve Aslan, 2013; Sever, 2013; Sever, 2015; Uz Erşahin, 2009; Ün Açıkgöz, 2011).

\section{Etkinliklerle çocuk edebiyatı metinlerinin Türkçe öğretiminde kullanımı}

1. Metnin Adı: Martı Ben Olsam /Sevim Ak

Türü: Hikâye Edici

Etkinlikler:

\section{OKUMA}

\section{Etkinlik - 1}

T.5.3.21 Görsellerden ve başlıklardan hareketle okuyacağı metnin konusunu tahmin eder.

1) Hayvan beslediniz mi? Anlatınız.

2) Metnin başlı̆̆ından hareketle metnin konusunu tahmin ediniz.

\section{T.5.3.4 Okuma stratejilerini kullanır.}

1) Öğrencilerden metin okunurken belirli yerlerde keserek devamını tahmin etmesi istenir.

\section{T.5•3.19.Metinle ilgili sorulara cevap verir.}




\section{T.5.3.20 Metnin konusunu belirler.}

1) Çocuk kuşun martı olduğunu neden anlamamıştır?

2) Teyze ve yeğeni martıyı nasıl beslemişlerdir?

3) Teyzesi neden pencerenin kenarından ayrılmamıştır?

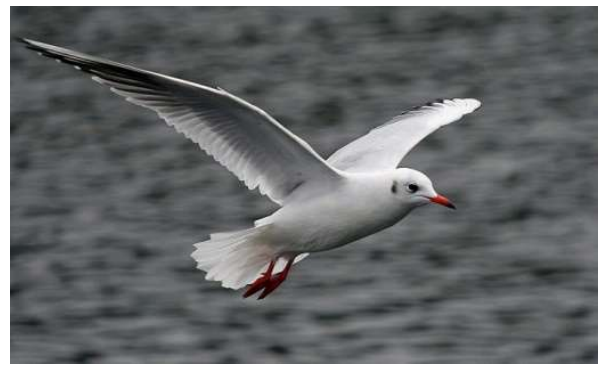

4) Martılar neden bağrışmışlardır?

5) Çocuk nasıl martı olabilir?

6) Siz de martı olmak ister miydiniz? Neden?

7) Okuduğunuz metnin konusu nedir?

\section{Etkinlik- 2}

\section{Söz Varlı̆̆ı}

\section{T.5•3.10 Kökleri ve ekleri ayırt eder.}

Aşağıdaki kök ve ekleri anlamlı kelimeler oluşacak şekilde eşleştirip boşluklara yazınız.
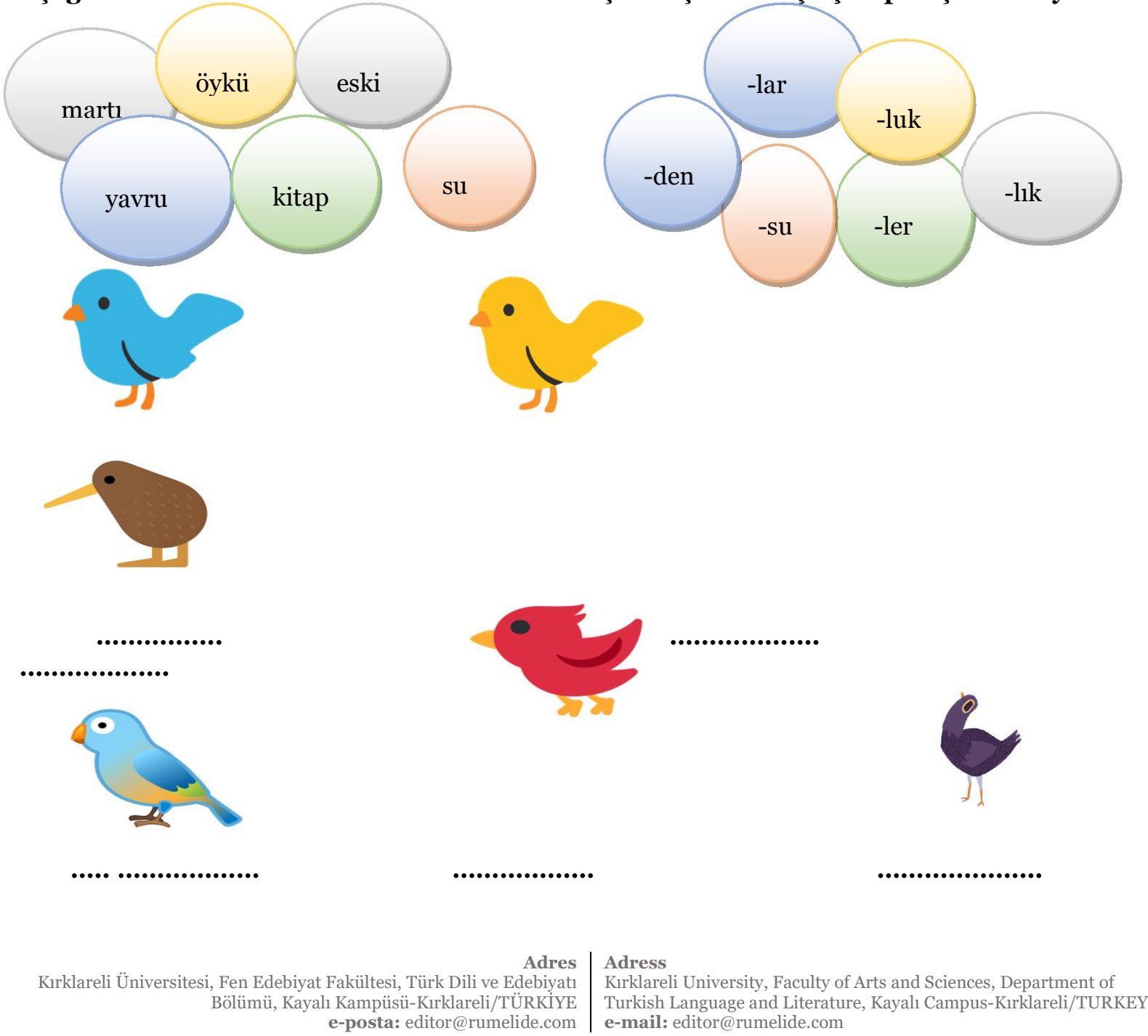


\section{DİNLEME / İZLEME}

\section{Etkinlik -3}

\section{Hayvanları tanıyorum.}

\section{T.5.1.6 Dinledikleri izlediklerine yönelik sorulara cevap verir.}

Öğrencilere çeşitli hayvan sesleri dinletilir hangi hayvan olduğunu tahmin etmesi istenir.

\section{Etkinlik- 4}

\section{Hayvanat bahçesinde bir gün.}

\section{T.5.1.8 Dinlediği izlediği hikâye edici metinleri canlandırır.}

Öğrencilere hayvanat bahçesi ile ilgili bir video izlettirilir. Daha sonra hayvanat bahçesindeki birer hayvanı canlandırıp aralarında diyalog kurmaları istenir.
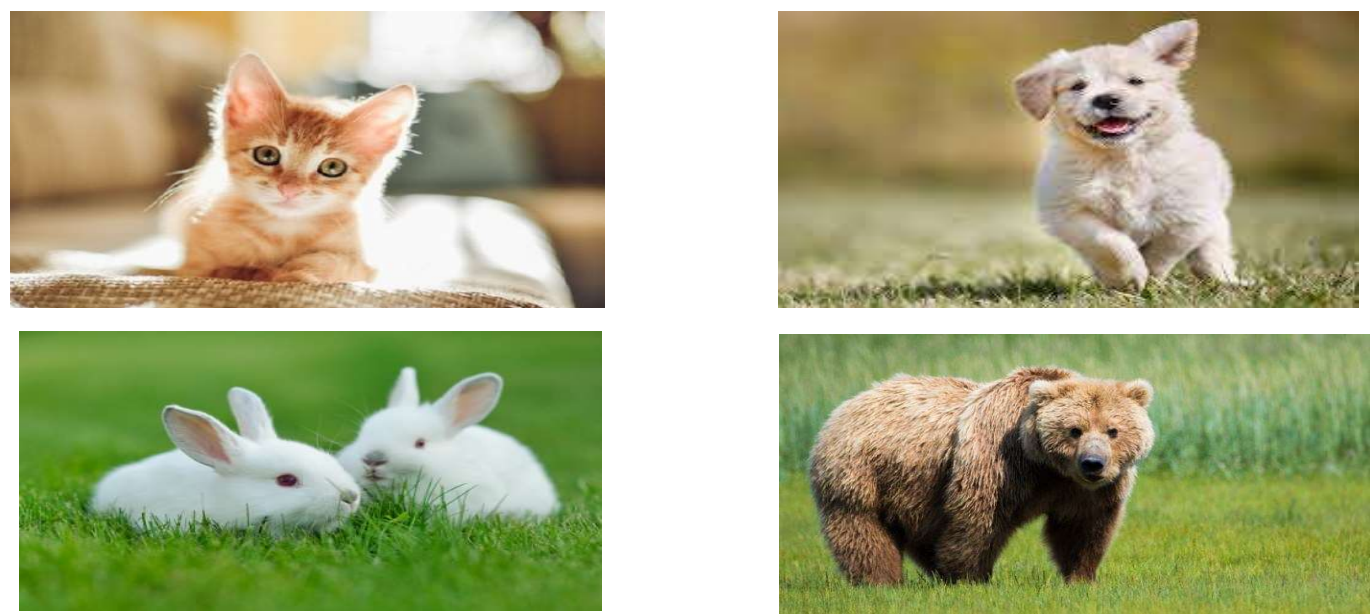

\section{KONUŞMA}

\section{Etkinlik- 5}

\section{Ben martı olsam...}

\section{T.5.2.3. Konuşma stratejilerini uygular.}

Çocuklar çember şeklinde oturtulur. Gözleri kapatılır.Martı sesleri dinletilir. Öğrencilerden martı olduklarını hayal etmeleri istenir. Bir sabah uyandığınızda martı olsaydınız ne yapardınız? Sorusu sorulur. Ellerine bir kalem verilir kalem elden ele dolaşır. Kalem elinde olan kişi konuşur.

\section{Etkinlik -6}




\section{Onların da hakkı var.}

\section{T.5.2.3 Konuşma stratejilerini uygular.}

Öğrencilerden hayvanların ne gibi haklara sahip olabileceği konusunda kendi aralarında tartışmaları daha sonra hayvan hakları ile ilgili afiş hazırlamaları istenir.

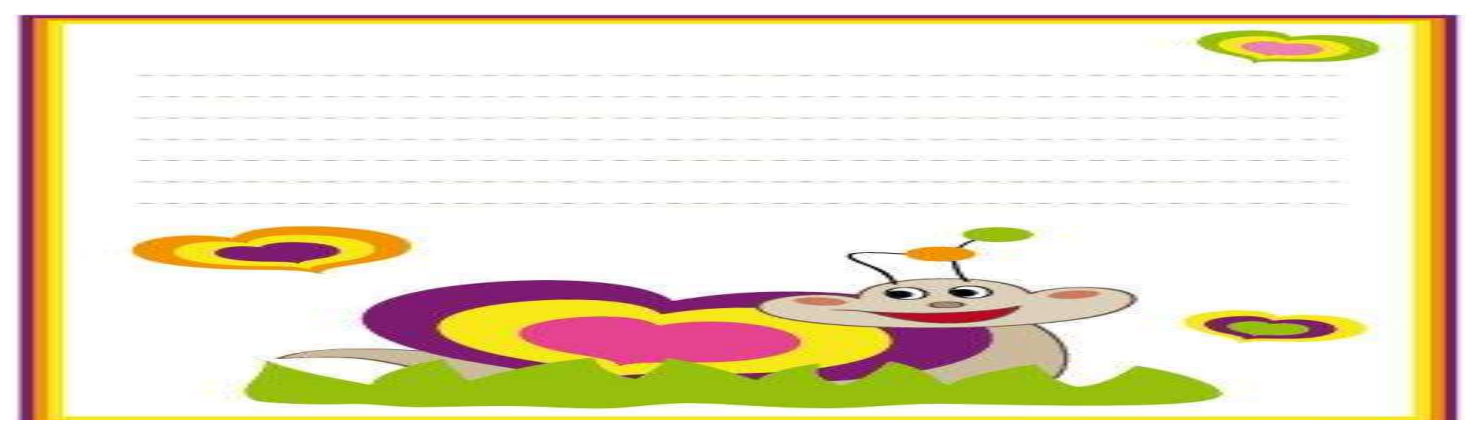

YAZMA

\section{Etkinlik- 7}

\section{Hayvanları seviyorum!}

\section{T.5.4.1. Şiir yazar.}

\section{T.5.4.2. Bilgilendirici metin yazar.}

\section{T.5.4.3 Hikâye edici metin yazar.}

Sınıf üç gruba ayrılır. Gruplara hayvan sevgisi ile ilgili çalışma yapılacağı söylenir. Grubun birinden şiir yazması diğerinden afiş hazırlaması son gruptan ise hikâye yazması istenir. Süre tutulur on dakikada bir gruplar değişir. Öğrenciler gittikleri grupta yapılan çalışmaları devam ettirir. Çalışmalar bitince okul panosunda sergilenir.

\section{Etkinlik -8}

\section{T.5.4.2. Bilgilendirici metin yazar.}

Öğrencilere sokak hayvanlarının ne gibi sorunları olabileceği hakkında düşünmeleri istenir. Öğrencilerden bir hayvanın yerine kendisini koyup onun ağzından sıkıntılarını yazması istenir. Daha sonra hep birlikte sorunlara çözüm aranır.

1. Metnin Adı: Kangurular Ülkesi Avustralya’ya Yolculuk /Gülten Dayığlu

Metnin Türü: Bilgilendirici (Gezi Yazısı)

\section{Etkinlikler:}

\section{OKUMA}




\section{Etkinlik -1}

T.6.3.15. Görselden ve başlıktan hareketle okuyacağı metnin konusunu tahmin eder.

1.Aşağıdaki görsellerden yola çıkarak metnin içeriğinde anlatılan ülkeyi tahmin ediniz.
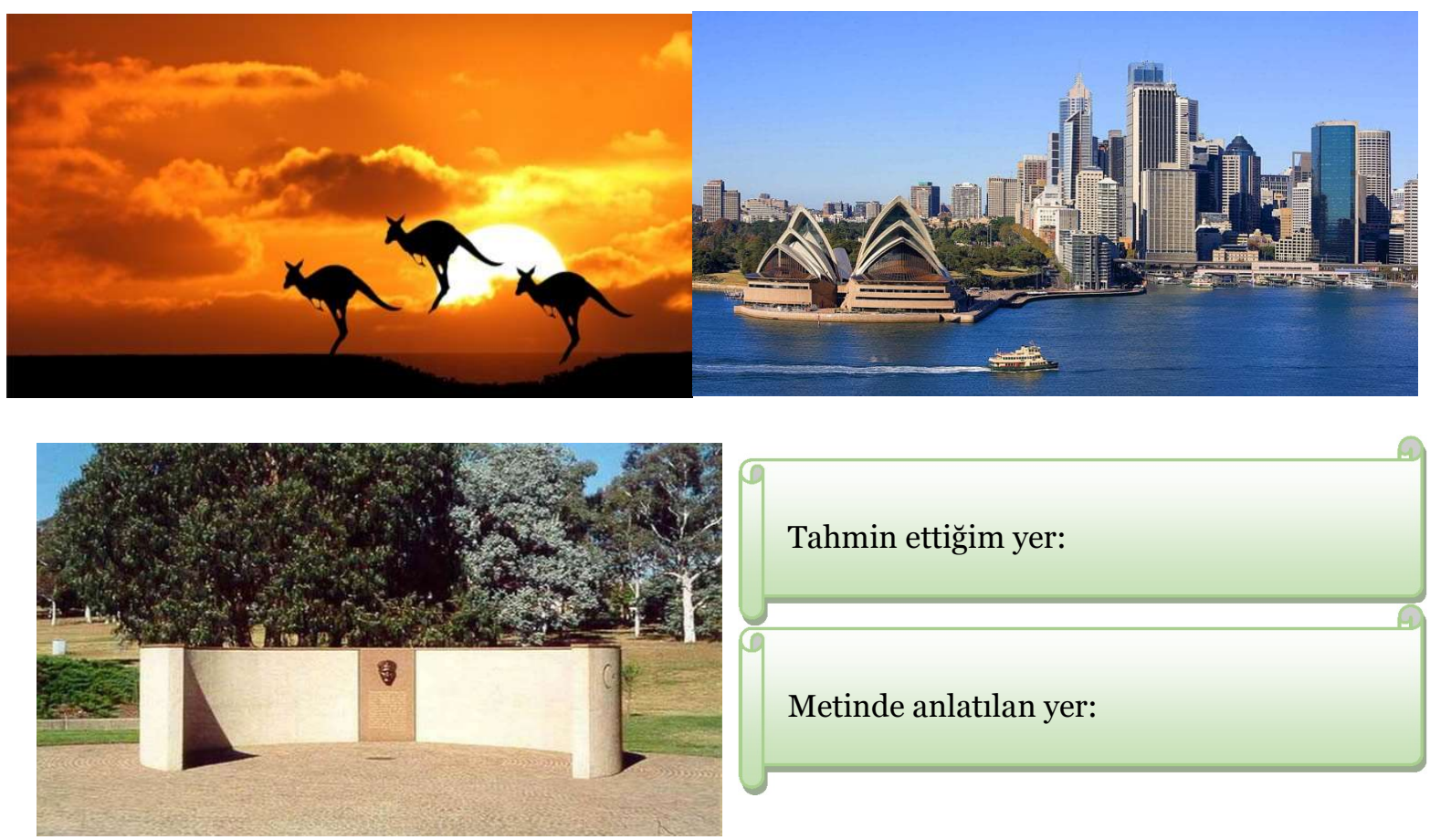

\section{Etkinlik -2}

\section{T.6.3.4. Okuma stratejilerini kullanır.}

T.6.3.18. Metinle ilgili sorular sorar.

T.6.3.20. Metnin ana fikrini/ana duygusunu belirler.

T.6.3.29. Okudukları ile ilgili çıkarımlarda bulunur.

3 N Ne biliyorum Ne öğrenmek istiyorum Ne öğrendim

Ne biliyorum?

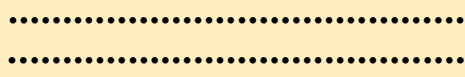

Ne öğrenmek istiyorum?

$\mathrm{Ne}$ öğrendim?

\section{Etkinlik -3}

T.6.3.17. Metinle ilgili soruları cevaplar.

\section{T.6.3.18. Metinle ilgili sorular sorar.}

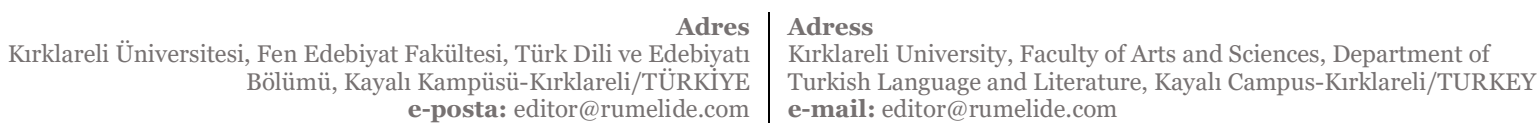


Öğrenciler metinle ilgili ikişer adet soru hazırlarlar ve hazırladıkları soruları mantar panonun üzerine pano iğnesi ile tuttururlar. Öğretmen de (analiz sentez ve değerlendirme) basamakları ile ilgili hazırlamış olduğu soruları mantar pano üzerine iğne ile tutturur. Sorular hazırlandıktan sonra öğrencilerden birisi gelir ve bir soru seçer. Seçtiği soruyu cevaplar. Cevapladıktan sonra kendisinden sonra soru cevaplaması için gelecek olan arkadaşını seçer ve yerine oturur. Tüm öğrenciler bitene kadar etkinlik devam eder.
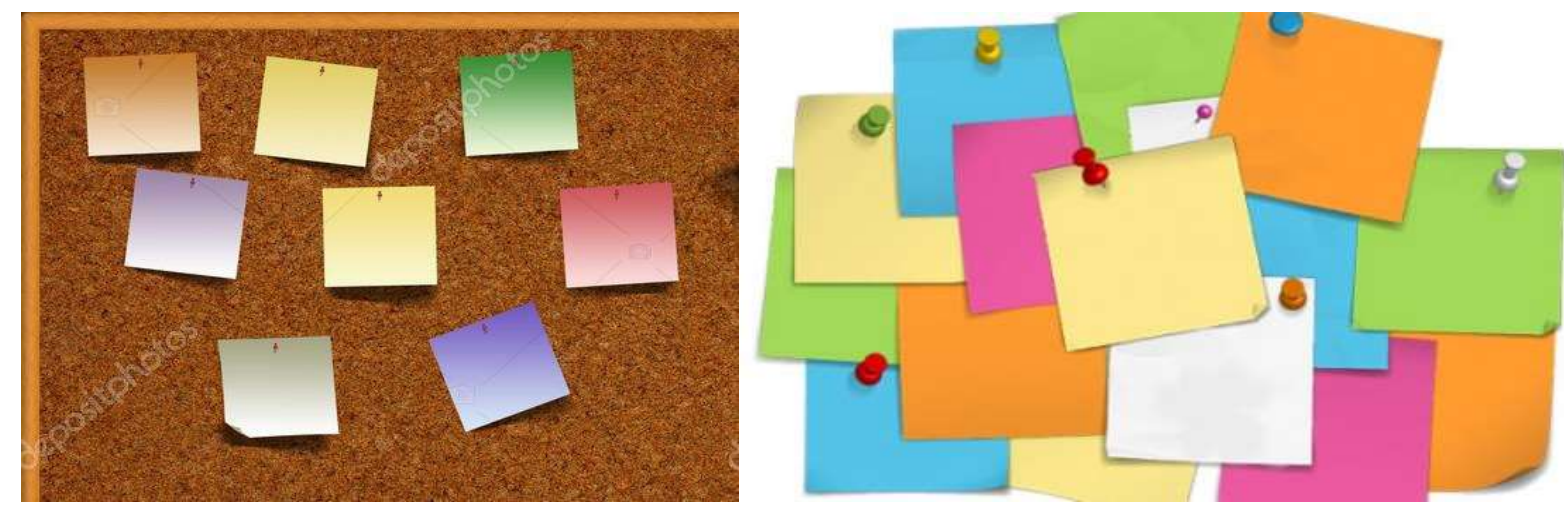

Etkinlik -4

\section{T.6.3.10. Edat, bağlaç ve ünlemlerin metnin anlamına olan katkısını açıklar.}

\section{T.6.3.13. Metni oluşturan unsurlar arasındaki geçiş ve bağlantı ifadelerinin anlama olan katkısını değerlendirir.}

\section{Edat ve Bağlaç Çarkı}

Öğretmen önceden belirdiği edat ve bağlaçları hazırlamış olduğu çarkın üzerine yazar. Öğrenciler çarkı çevirir ve gelen sözcük/ sözcük grubunun edat mı bağlaç mı olduğunu söyler. Sonrasında çarkta gelen edat veya bağlaçla ilgili bir cümle kurar. Kurduğu sözcüğe edatın ya da bağlacın nasıl bir anlam kattığını açıklar ve yerine oturur. Çarkı çevirmek için başka bir öğrenci gelir ve etkinlik bu şekilde devam eder. Örnekler: Ama, fakat, lâkin, ancak, yalnız, oysa, oysaki, hâlbuki ve, ile, çünkü, zira, madem, mademki, veyahut, yahut, veya, ya da, şayet, eğer, ise ve yalnız, ancak, sadece, sade, tek, bir için, diye, üzere kadar, denli gibi ile değil...

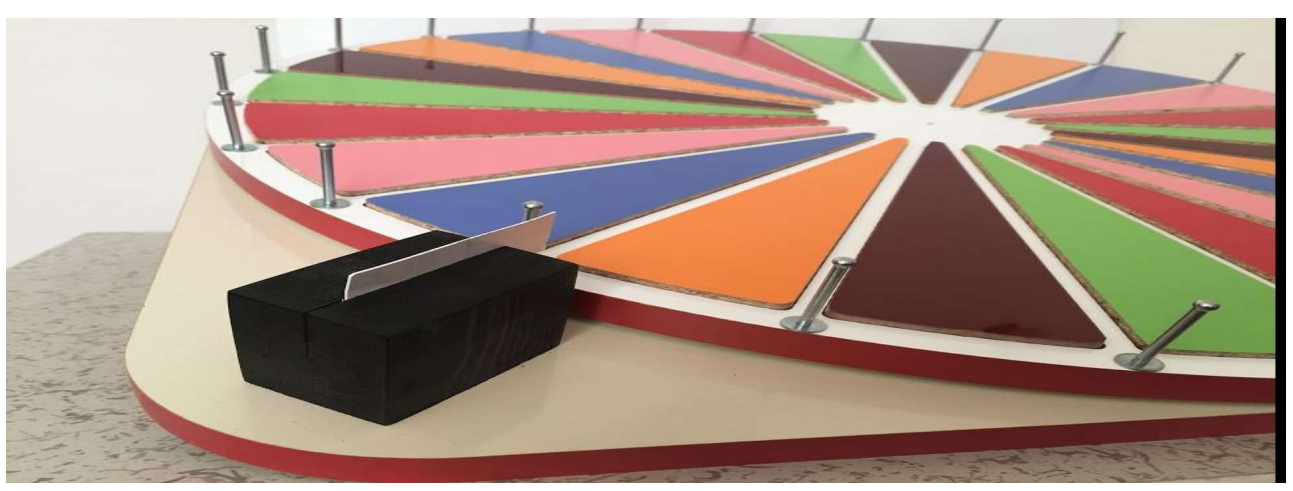




\section{DİNLEME / İZLEME}

\section{Etkinlik -5}

T.6.1.1. Dinlediklerinde/izlediklerinde geçen olayların gelişimi ve sonucu hakkında tahminde bulunur.

\section{T.6.1.10. Dinlediklerinin/izlediklerinin içeriğini değerlendirir.}

\section{T.6.1.11. Dinledikleriyle/izledikleriyle ilgili görüşlerini bildirir.}

Derse başlamadan önce Avustralya ve Avustralya'daki Atatürk anıtı ile ilgili aşağıda linki verilen videolardan seçilen iki tanesi izletilir ve öğrencilerin izlediklerine dair görüşleri alınarak metnin başlı̆̆ından da hareketle metnin içeriğini tahmin etmeleri istenir.

https://www.youtube.com/watch?v=x_9poyquCas

https://www.youtube.com/watch?v=OjQlGGJWTyE

https://www.youtube.com/watch?v=b8AXDf1GqD8

https://www.youtube.com/watch?v=6zGadliOUfU

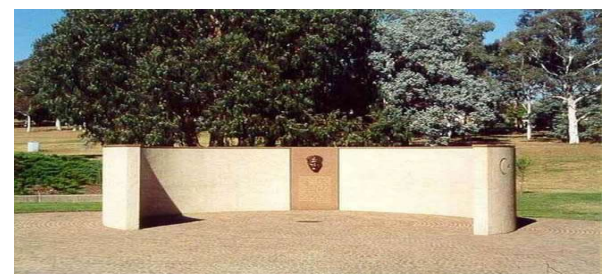

\section{KONUŞMA}

\section{Etkinlik -6}

\section{T.6.2.2. Hazırlıksız konuşma yapar.}

\section{T.6.2.3.Konușma stratejilerini uygular.}

\section{T.6.2.4. Konuşmalarında beden dilini etkili bir şekilde kullanır.}

\section{Nereyi Gezdim?}

Öğretmen öğrencilerine daha önceden hazırlamış olduğu yeşil, mavi, beyaz ve sarı renkli kâğıtları dağıtır. Yeşil kâğıt tümüyle katılıyorum, mavi kâğıt katılıyorum, beyaz kâğıt kararsızım ve sarı kâğıt ise katılmıyorum ifadelerini temsil eder. Sonrasında öğretmen öğrencilerden gezip gördüğü ve en çok beğendiği bir yeri belirlemelerini ister. Öğrencilerden belirledikleri yeri sırayla tahtaya çıkıp anlatmalarını söyler. Öğrenci konuşmasını bitirdikten sonra öğretmen arkadaşınız gördüğü yeri çok güzel anlattıysa yeşil kâğıdı, güzel anlattıysa mavi kâğıdı, karar veremiyorsanız beyaz kâğıdı ve iyi anlatamadığını düşünüyorsanız sarı kâ̆̆gdı kaldırın der ve kaldırılan kâğıtların renklerini sayıp tahtaya yazar. Bütün öğrenciler konuşmasını bitirdikten sonra en çok yeşil kart kaldırılan kişi/kişiler belirlenir. 


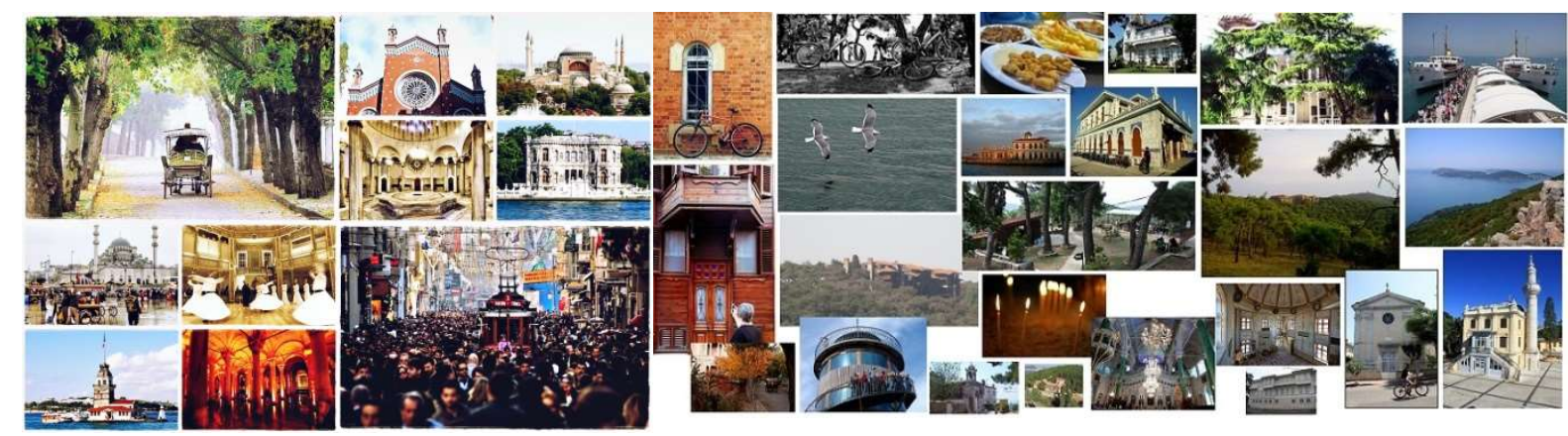

\section{Etkinlik -7}

\section{T.6.2.2. Hazırlıksız konuşma yapar.}

\section{T.6.2.4. Konuşmalarında beden dilini etkili bir şekilde kullanır.}

\section{T.6.2.5. Kelimeleri anlamlarına uygun kullanır.}

\section{Nesi var?}

Öğretmen öğrencilere Türkiye'deki şehirlerle ilgili nesi var oyunu oynayacaklarını söyler. Sinıftan gönüllü öğrenci dışarıya çıkar. Öğretmen öğrencilerle beraber bir şehir belirler ve öğrenci sınıfa çağrılır. Gelen öğrenci nesi var diye sorar ve şehri bilene kadar sormaya devam eder. Belirlenen şehir bulunduğu zaman başka bir öğrenci dışarıya çıkar ve başka bir öğrenci belirlenir. Etkinlik bu şekilde devam eder.
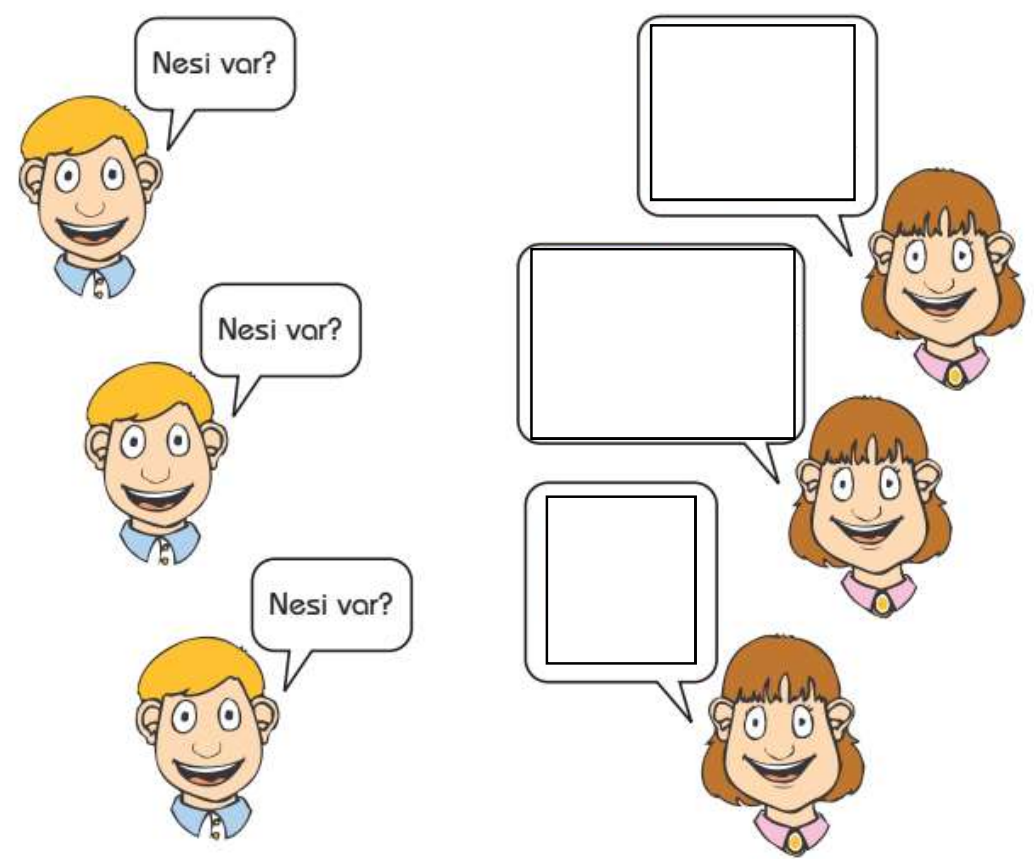


\section{YAZMA}

\section{Etkinlik -8}

\section{T.6.4.2. Bilgilendirici metin yazar.}

\section{T.6.4.4. Yazma stratejilerini uygular.}

T.6.4.8. Yazdıklarının içeriğine uygun başlık belirler.

\section{T.6.4.9. Yazılarında uygun geçiş ve bağlantı ifadelerini kullanır.}

Okuduğunuz metnin gözünüzde canlandırdıklarını aşağıda verilen kısma resmediniz. Çizdiğiniz resmin içeriği ile ilgili bilgilendirici bir metin yazınız.

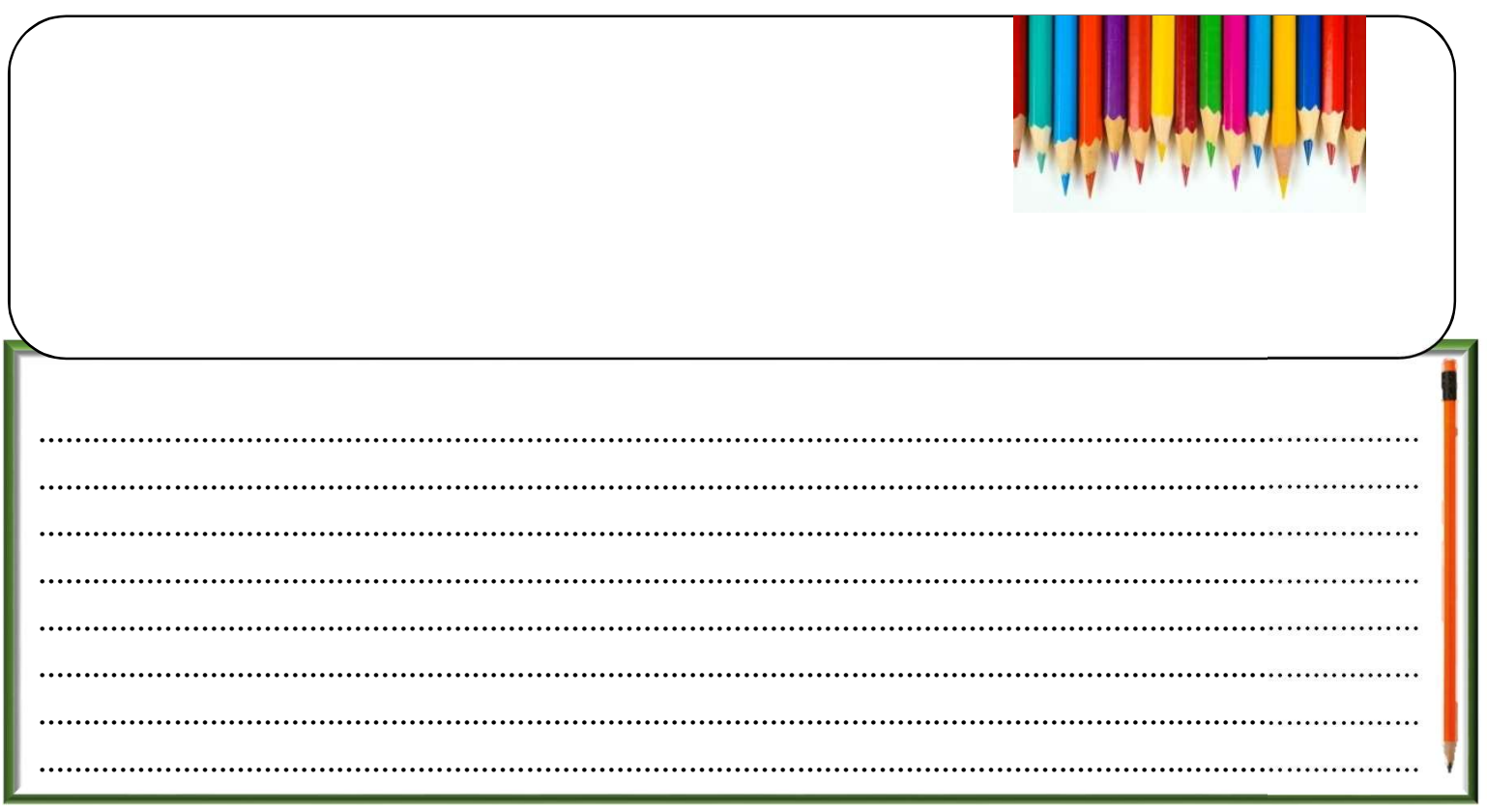

\section{Etkinlik -9}

\section{T.6.4.2. Bilgilendirici metin yazar.}

\section{T.6.4.6. Bir işi işlem basamaklarına göre yazar.}

\section{T.6.4.10. Yazdıklarını düzenler.}

\section{T.6.4.11. Yazdıklarını paylaşır.}

Öğretmen öğrencilere renkli kâğıtlar dağıtır. İstediği renkte kâğgdı alan öğrenci gezip gördüğü bir yeri verilen kâğıda yazarak anlatır ve gezdiği yerin neresi olduğunu yazmaz. Yazma işi bittikten sonra kâğıda ismini yazarak kutuya atarlar. Bütün öğrenciler yazınca herkes kutudan bir kâğıt alır ve okur. Yazılan yerin neresi olduğunu tahmin etmeye çalışır. 


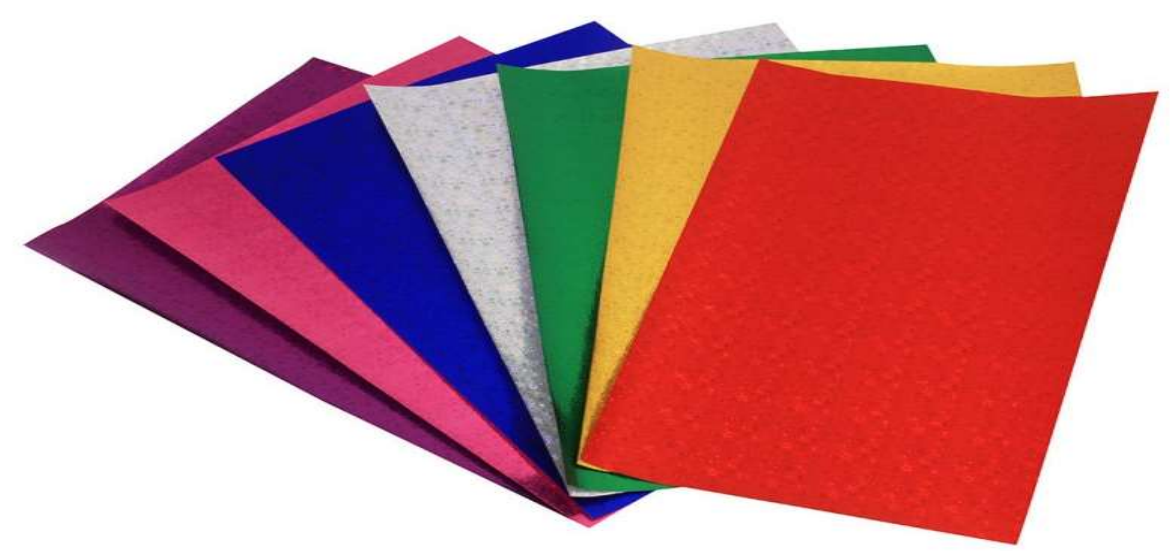

2. Metnin Adı: Vatan Türküsü / Fazıl Hüsnü Dağlarca

\section{Metnin Türü: Şiir}

Etkinlikler:

\section{OKUMA}

\section{Etkinlik -1}

T.7.3.14. Görsellerden ve başlıktan hareketle okuyacağı metnin konusunu tahmin eder.

\section{T.7.3.15. Okuduklarını özetler.}

\section{T.7.3.16. Metnin konusunu belirler.}

\section{T.7.3.17. Metnin ana fikrini/ana duygusunu belirler.}

\section{T.7.3.18. Metindeki yardımcı fikirleri belirler.}

Aşağıda verilen “Ne biliyorum?” ve “Ne öğrenmek istiyorum?” Kutucuklarını metni okumadan önce Ne öğrendim kutucuğunu ise metni okuduktan sonra doldurunuz.

\begin{tabular}{|c|c|c|}
\hline Ne biliyorum? & Ne öğrenmek istiyorum? & Ne öğrendim? \\
\hline 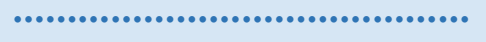 & $\cdots \cdot$ & (............ \\
\hline & . & …....... \\
\hline 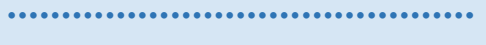 & $\cdots \cdots \cdot$ & ............. \\
\hline 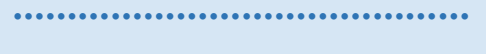 & 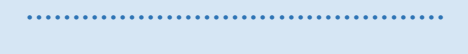 & …...... \\
\hline
\end{tabular}

\section{Etkinlik -2}

\section{T.7.3.19. Metinle ilgili soruları cevaplar.}

\section{T.7.3.20. Metinle ilgili sorular sorar.}


Şiirin size çağrıştırdıkları ile ilgili verilen kâğıda bir adet soru yazınız. Yazdığınız soruya cevap vermesini istediğiniz kişiyi belirleyiniz ve sorunuzu arkadaşınıza sorunuz.( Bütün öğrenciler birer adet soru yazarlar ve cevaplamasını istediği arkadaşı yine kendisi belirler.)

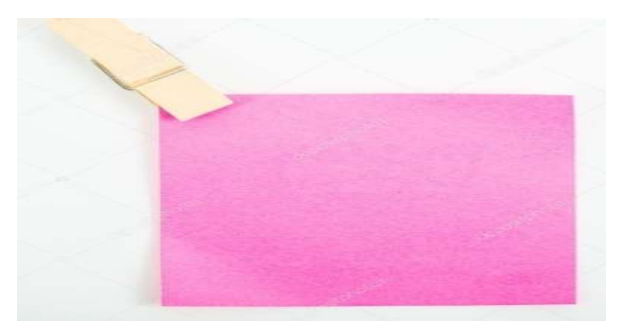

\section{Etkinlik -3}

\section{T.7.3.19. Metinle ilgili soruları cevaplar.}

\section{T.7.3.20. Metinle ilgili sorular sorar.}

Öğrenciler şiiri okuduktan sonra gönüllü üç öğrenci tahtaya kalkar. Öğrencilerden bir tanesi sorulan soruları cevaplayan, diğer ikisi de soru soran öğrenciler olur. Şiirin ana duygusu ile bağlantılı olarak öğrenciler ikişer tane soru sorarlar ve diğer öğrenci bu soruları cevaplar. Sonrasında öğrenciler değişerek devam eder.

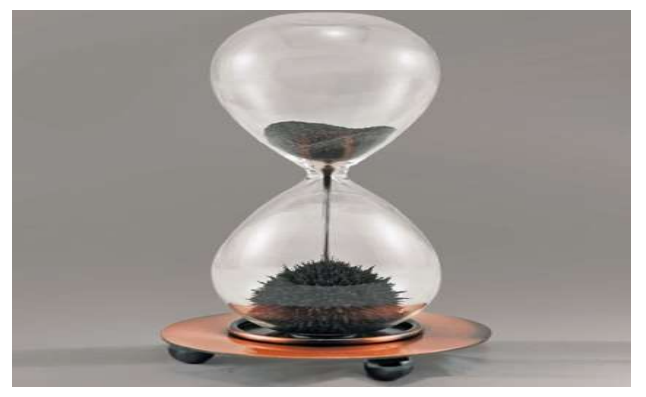

\section{DİNLEME / İZLEME}

\section{Etkinlik -4}

\section{K T.7.1.12. Dinlediklerinin/izlediklerinin içeriğini değerlendirir.}

Aşağıda linki verilen çizgi film öğrencilere izletilir ve okudukları şiirle arasında bağlantı kurmaları istenir. Sonrasında izledikleri videonun içeriğini değerlendirmeleri istenir.

https://www.youtube.com/watch?v=ac_TbXYdy28

Video izlendikten sonra gönüllü öğrenciler tarafından içerikle alakalı küçük bir doğaçlama tiyatro yapmaları istenir. 


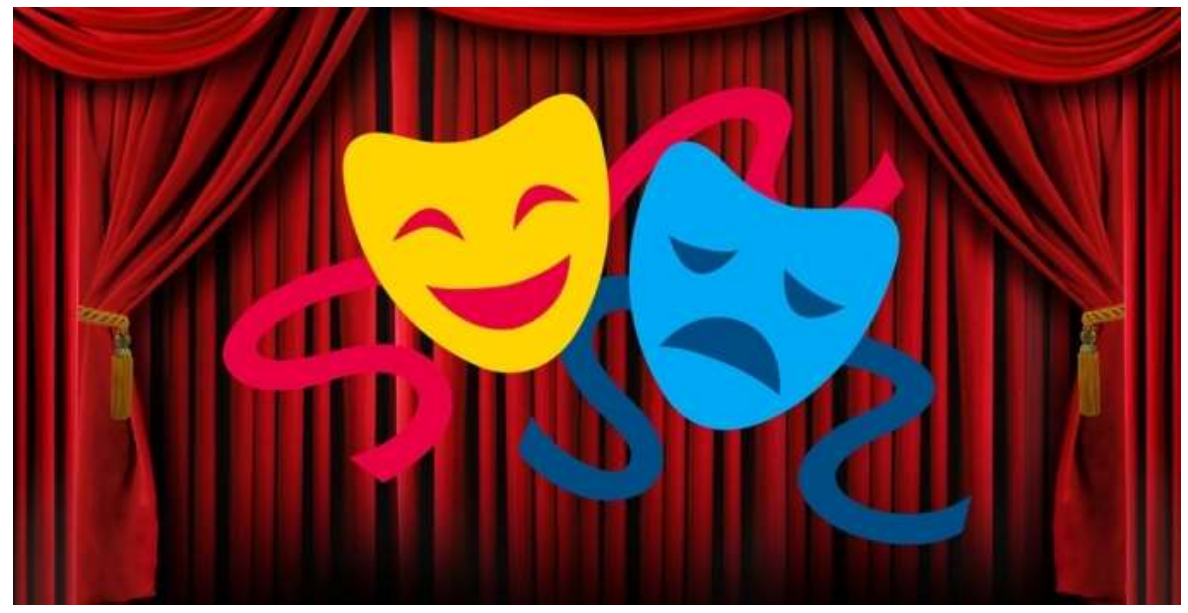

KONUŞMA

\section{Etkinlik -5}

\section{T.7.2.2. Hazırlıksız konuşma yapar.}

\section{T.7.2.3. Konuşma stratejilerini uygular.}

Öğretmen sınıfa ev şeklinde hazırlamış olduğu materyal ile gelir ve bu evin bir sürprizi olduğunu söyler. İlk öğrenci gelir ve evin çatısından tutarak yukarıya doğru kaldırır. Sonrasında evin içinde kutular çıkar bütün kutular açılır ve resimlere bakılır. Sonra bir öğrenci gelir ve istediği bir görseli seçer. Bu görseli arkadaşlarına anlatmaya çalışır. Öğrenciler dinlerler ve arkadaşının anlattığı görselin neresi ya da ne olduğunu bulmaya çalışırlar. Bütün öğrenciler bitene kadar etkinlik devam eder.

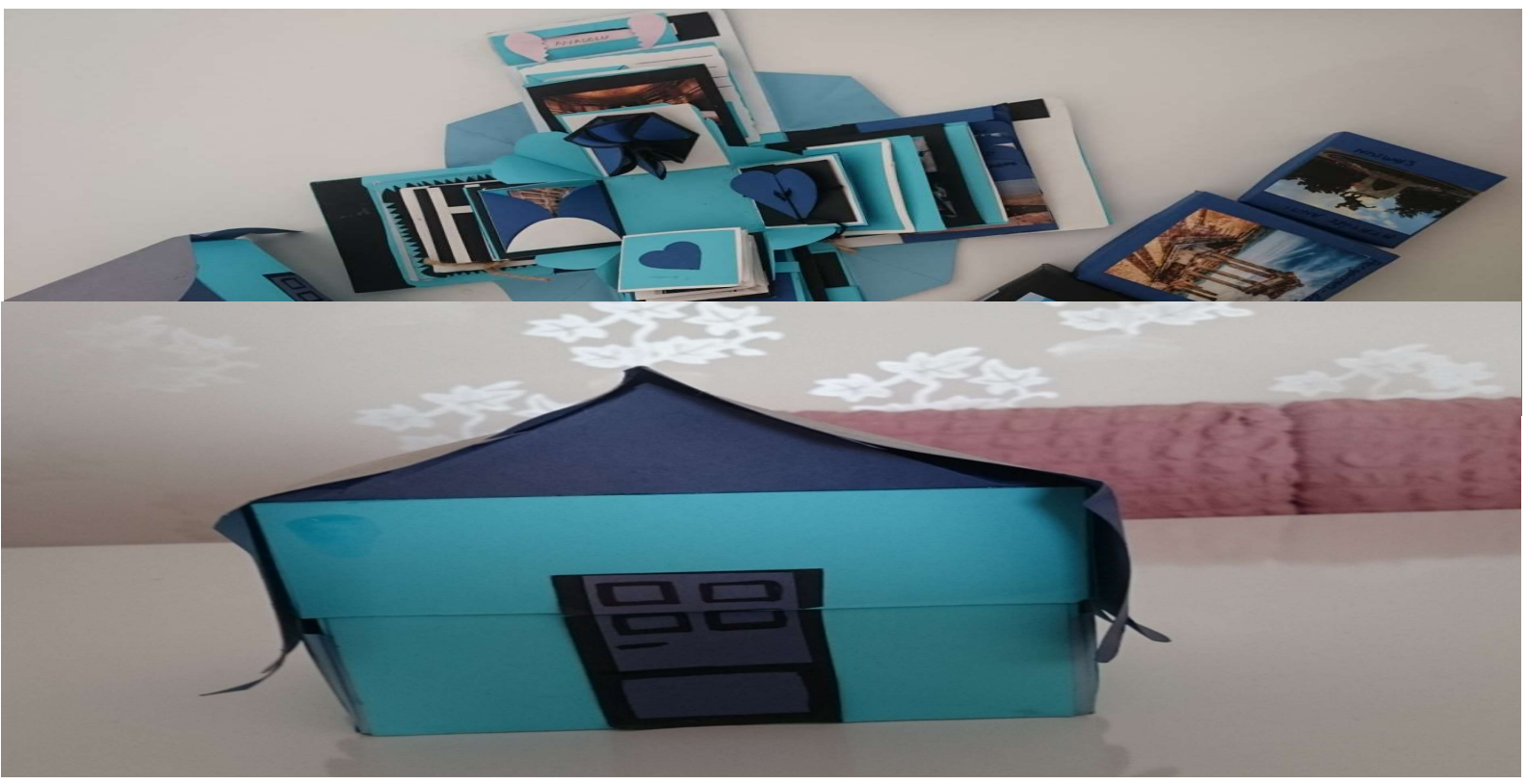




\section{T.7.2.2. Hazırlıksız konuşma yapar.}

\section{T.7.2.3. Konuşma stratejilerini uygular.}

\section{T.7.2.4. Konuşmalarında beden dilini etkili bir şekilde kullanır.}

\section{T.7.2.5. Kelimeleri anlamlarına uygun kullanır.}

\section{T.7.2.6. Konuşmalarında uygun geçiş ve bağlantı ifadelerini kullanır.}

Öğretmen aşağıda verilen fotoğrafların çıktısını alıp sınıf tahtasına asar. Öğrenciler bu fotoğraflara bakar ve fotoğrafların düşündürdüklerini resmederler ve çizdikleri resmin altına sadece isimlerini yazarlar ve öğretmen çizilen bütün resimleri toplar. Sonrasında öğrenciler sırayla tahtaya çıkar ve çizilen resimlerden birisini seçer. Çizilen resmi arkadaşlarına gösterir ve arkadaşının düşündüklerini anlamaya ve anlatmaya çalışır. Konuşması bittikten sonra resmi çizen arkadaşına doğru tahmin edip etmediği sorulur ve resmi çizen anlatmak istediklerini söyler. Bütün çizimler bitene kadar etkinlik devam eder.

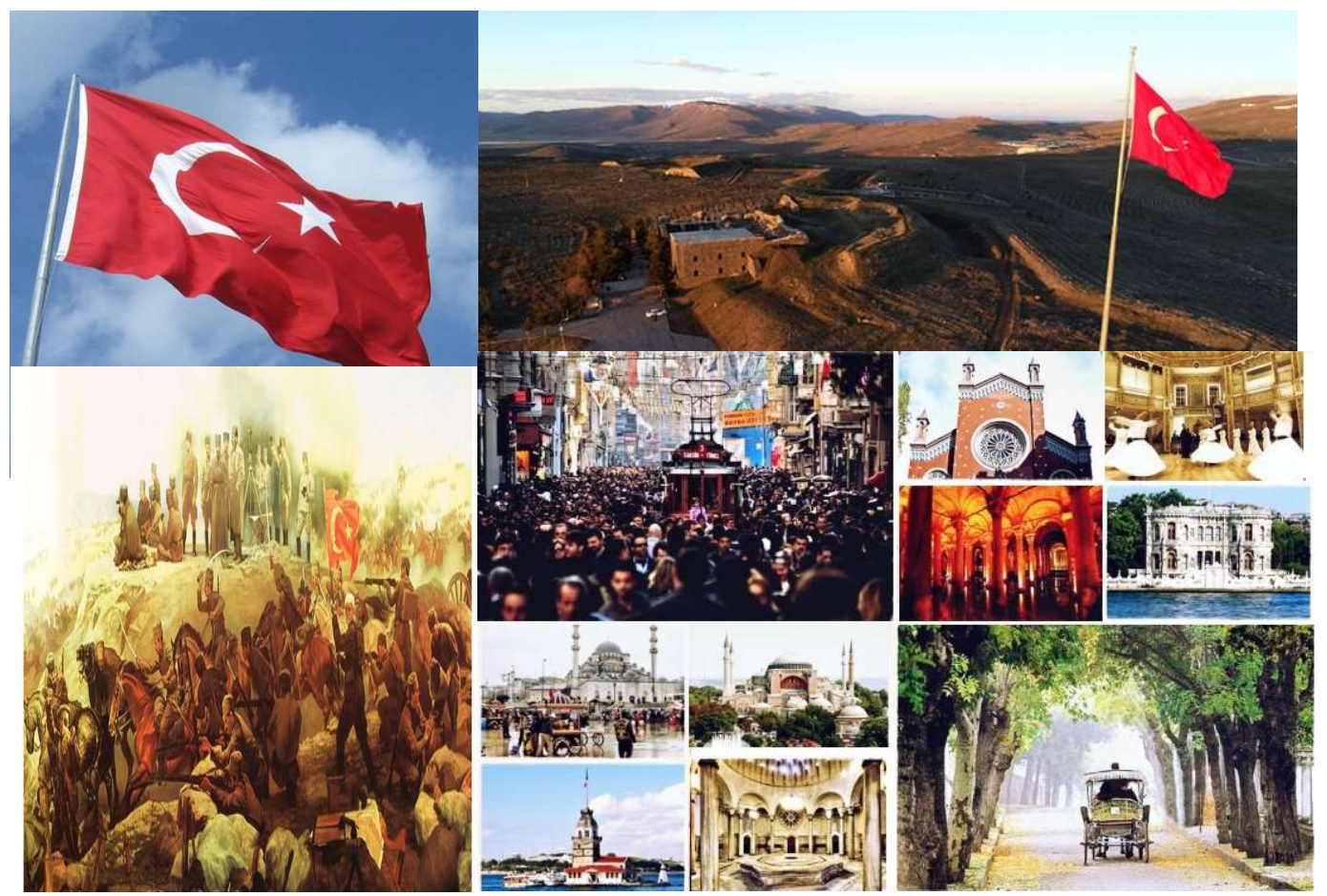

YAZMA

\section{Etkinlik -7}

\section{T.7.4.11. Kisa metinler yazar.}

Aşağıda verilen karikatürler tamamlayınız ve arkadaşlarınızla paylaşınınız. 

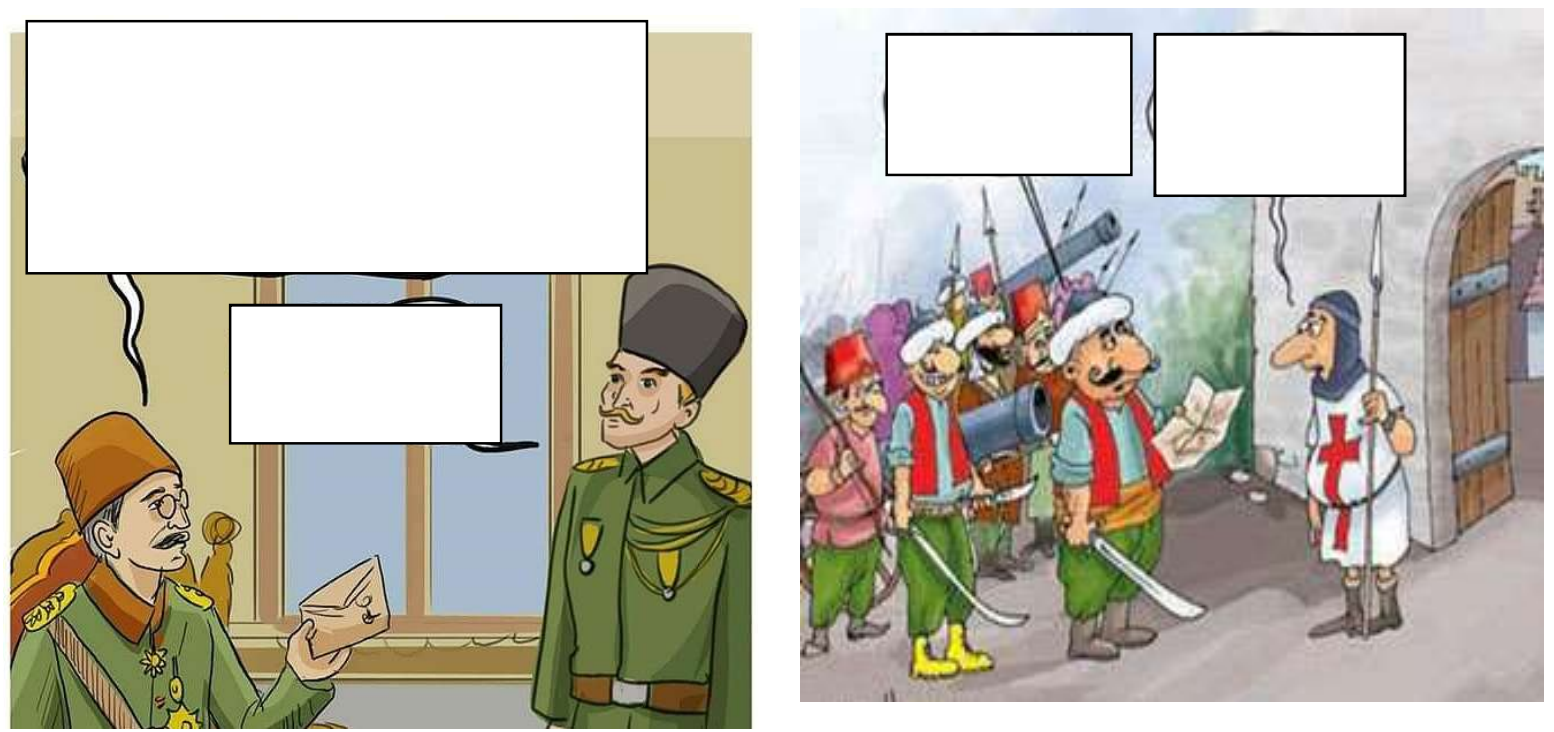

\section{Etkinlik -8}

\section{T.7.4.3. Hikâye edici metin yazar.}

Metnin konusunu ve ana fikrini sınıfta açıklayınız. Ana fikrin belirkenmesinin ardından sınıfa getirdiğiniz A4 ebadındaki kağıda "Vatan Türküsü" adlı şiirin konusu ve ana fikri etrafında, metne uygun bir başlık belirleyerek kendi kelimelerinizle hikaye türünde bir metin yazınız.

\section{Etkinlik -9}

Öğretmen sınıfı dört gruba ayırır. Her grup üzerinde noktalama işaretlerinin yazılı olduğu kâğıtlardan bir tanesini seçer. Seçilen kâğıtların içini açarlar. Kâğıtta bir paragraf verilmiştir ve bu paragrafta noktalama işaretleri boş bırakılmıştır. Öğrenciler boşlukları uygun noktalama işareti ile doldururlar ve işaretin kullanılma sebebini açıllarlar. İlk bitiren grup cevap kutuna gelip düğmeye basar ve cevaplar düşer. Öğrenciler kontrol ederler. İlk ve hepsini doğru yapan grup yarışmayı kazanır. 


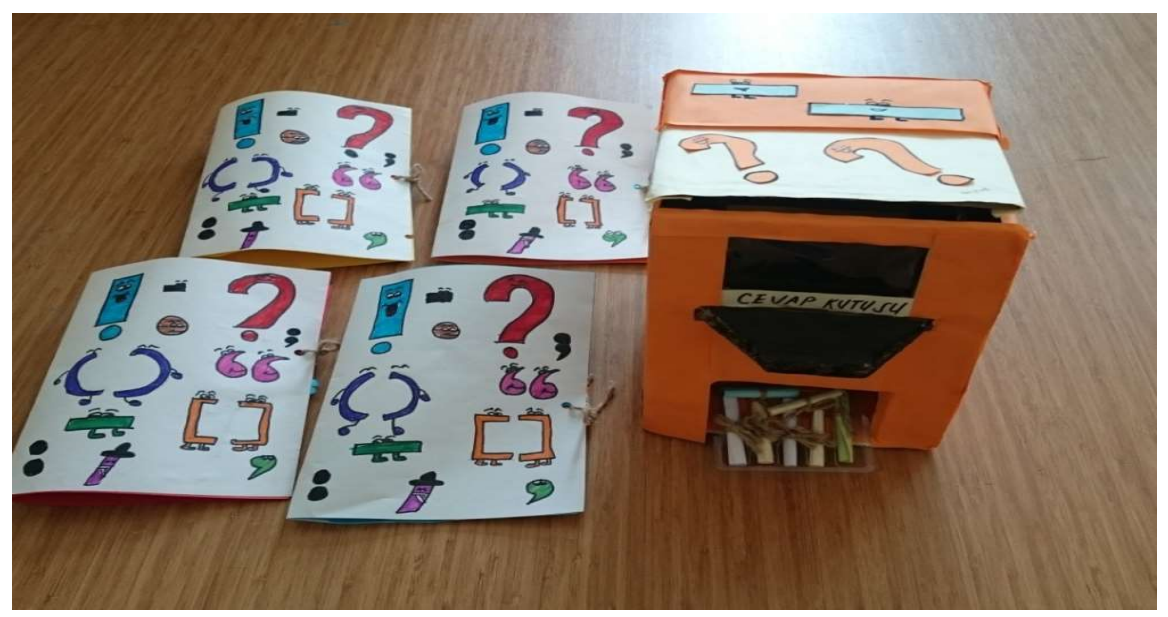

\section{Sonuç ve tartışma}

Türkçe öğretiminde, öğrencilerin dinleme, konuşma, okuma, yazma gibi temel dil becerilerinin geliştirilmesi amaçlanmaktadır. Dinleme ve okuma anlama gücünü geliştirmeye yönelik; konuşma ve yazma ise anlatma becerilerini geliştirmeye yönelik etkinliklerden oluşmaktadır. Bu becerilerin geliştirilmesinde yazınsal ve öğretici nitelikli metinlerden yararlanılmaktadır. Bu çalışmada çocuk edebiyatının özgün ürünlerinden seçilen metinlere yönelik etkinlik örnekleri oluşturulmuştur.

Alanyazın incelendiğinde Türkçe ders kitabına metin seçiminde hedef kitlenin yaş düzeyine uygun nitelikli çocuk edebiyatı yapıtlarından yararlanılması gerektiği vurgulanmaktadır (Canlı, 2015; Çer, 2016; Sever, Kaya ve Aslan, 2013; Sever, 2015, Temizyürek, 2003; Uz Erşahin, 2009). Dil öğretiminde, öğrenciye sunulan metinlerin önemi büyüktür (Baki ve Karakuş, 2012: 6). Türkçe öğretimi ile okuma kültürü edinmiş düşünen duyarlı bireylerin yetiştirilmesi nitelikli çocuk edebiyatı ürünlerinin öğrenmeöğretme ortamında kullanımına bağlıdır. Baş’a (2015: 32-33) göre çocukların anlama ve anlatma becerilerin geliştirilmesi eğitim ortamlarında çocuk edebiyatı ürünlerinin kullanımına bağlıdır. Öztürk'e (2014) göre de çocuk kitapları, okuma becerisinin alışkanlığa dönüşmesinde, temel dil becerileri olan dinleme, konuşma ve yazma becerilerinin gelişiminde de oldukça etkilidir. Sever, Kaya ve Aslan'a (2013: 19) göre ise öğrencilerin bu becerileri kazanmaları için bu metinlerin zenginleştirilmiş çok uyaranlı eğitim ortamlarında ele alınıp işlenmesi gerekmektedir.

Türkçe ders kitaplarına seçilecek metinlerin niteliği kadar metinlerle birlikte hazırlanacak temel dil becerilerine yönelik etkinlikler ve bu etkinliklerin etkin yöntem ve tekniklerle işlenmesi de önem arz etmektedir. Güneş'e (2017: 48) göre etkinlikler öğrenmeyi kolaylaştırmaktadır. Etkinlikler öğrencilerin bilgileri keşfetme, bütünleştirme, mantığını yakalama, becerileri geliştirme ve başkalarıyla paylaşmalarına yardım etmektedir (Güneş, 2012: 40). Bu etkinlikler ile Türkçe Dersi Öğretim Programı'nda belirlenen amaç ve kazanımlara da ulaşılmaya çalışılmaktadır (Dilidüzgün, 2010, s.14). Bu nedenle de metinlere yönelik hazırlanacak etkinliklerin özenle hazırlanması gerekmektedir.

Göçer (2010: 342) öğrenme ve öğretme süreci etkinliklerinin çok uyaranlı ve etkileşimli bir ortamda yürütülmesinin önemine işaret etmektedir. Lüle Mert (2014) de Türkçe öğretiminden yeterli verimin elde edilmesi için uygulamaya dayalı çalışmaların, etkinliklerin yapılmasının önemine değinmektedir. Mevcut çalışmada da çocuklara yönelik oluşturulmuş metinlerle birlikte öğrencilerin eğlenerek öğrenecekleri etkinliklere yer verilmiştir. 


\section{Kaynakça}

Açıgöz, K. Ü. (2003). Etkili Öğrenme ve Öğretme. İzmir: Eğitim Dünyası.

Baki, Y. ve Karakuş, N. (2012). Türkçe Öğretiminde Öğretim Teknolojileri ve Materyal Tasarımı. Ankara: Pegem Akademi.

Baş, B. (2014). Çocuk Edebiyatı. A. Güzel ve H. Karatay (Ed.) içinde, Türkçe Öğretimi (ss. 469-520). Ankara: Pegem Akademi.

Baş, B. (2015). Türkçe Öğretimi Açısından Çocuk Edebiyatı. Ankara: Pegem Akademi.

Canlı, S. (2015). Türkçe Ders Kitaplarına Seçilecek Metinlerin Belirlenmesinde Çocuğa Görelik İlkesi. Dil Eğitimi ve Araştırmaları Dergisi, 1(1), 98-123,

Çer, E. (2016). Türkçe Öğretiminde Çocuğa Görelik İlkesine Uygun Edebiyat Yapıtlarının Önemi. İlköğretim Online, 15(4), 1399-1410, 2016. [Online]:http://ilkogretim-online.org.tr doi: http://dx.doi.org/10.17051/io.2016.22814.

Dilidüzgün, S..(2010). Türkçe Derslerinde Metin Etkinliklerinin Okuma-Anlama Kazanımlarını Gerçekleştirme Yeterliği- Bir Öykü Örneği. Hasan Ali Yücel Eğitim Fakültesi Dergisi Sayı 13 (2010-1), 13-30

Göçer, Ali (2010). “Türkçe Öğretiminde Çok Uyaranlı Bir Öğrenme Ortamı Oluşturmak İçin Seçkin Edebî Ürünlerden Yararlanma", Türklük Bilimi Araştırmaları, 27 (341-369).

Göçer, A. (2017). Türkçe Özel Öğretim Yöntemleri. Ankara: Pegem Akademi.

Güneş, F. (2012). Testlerden etkinliklere Türkçe öğretimi. Dil ve Edebiyat Eğitimi Dergisi, 1(1), 31-42.

Güneş, F. (2015). Etkinliklerle Hızlı Okuma ve Anlama. Ankara: Pegem Akademi.

Güneş, F. (2017). Türkçe öğretiminde etkinlik yaklaşımı. Ana Dili Eğitimi Dergisi, 5(1), 48-64

Güleryüz, H. (2013). Yaratıcı Çocuk Edebiyatı. Ankara: Edge Akademi.

Hasırcı, S. (2015).Türkçe Öğretiminde Çok Uyaranlı Eğitim Ortamlarının Yapılandırılmasına Dönük Bir Model Önerisi (5-8. Sınıf Örneği). Yayınlanmamış Doktora Tezi. Ankara Üniversitesi Eğitim Bilimleri Enstitüsü, Ankara.

Karadüz, A. (2016). Eleştirel Paradigma ve Dil Öğretimi. A. Karadüz (Ed.) içinde, Eleştirel Dil Becerileri Kuram ve Uygulama (ss. 1-34). Ankara: Pegem Akademi.

Karasar, N. (2017). Bilimsel Araştırma Yöntemleri (32. Basım). Ankara: Nobel.

Kavcar, C., Oğuzkan, F. ve Sever, S. (2005). Türkçe Öğretimi. Ankara: Engin.

Lüle Mert, E. (2014) Türkçenin eğitimi ve öğretiminde dört temel dil becerisinin geliştirilmesi sürecinde kullanılabilecek etkinlik örnekleri. Ana Dili Eğitimi Dergisi, 2(1), 23-48.

Nas, R. (2014). Örneklerle Çocuk Edebiyatı. Bursa: Ezgi.

Özbay, M. (2014). Türkçe Özel Öğretim Yöntemleri II. Ankara: Öncü Kitap.

Özdemir, E. (1983). Anadili Öğretimi. Türk Dili, Dil Öğretimi Özel Sayısı. Ankara: Türk Dil Kurumu. s.538.

Öztürk, B. (2014) Türkçe Öğretiminde Çocuk Kitaplarından Yararlanma Örneği: Mutlukent'in Yöneticisi. http://www.tdk.gov.tr/images/images/585.pdf 23.05.2019 tarihinde erişildi.

Sever, S. (2000). Türkçe Öğretimi ve Tam Öğrenme. Ankara: Anı.

Sever, S. (2003). Türkçe Öğretiminde Yeni Yapılanma Çalışmaları. TÜBAR-XIII-Bahar, s.27-38.

Sever, S. (2013). Çocuk ve Edebiyat. İzmir: Tudem.

Sever, S., Kaya, Z. ve Aslan, C. (2013). Etkinliklerle Türkçe Öğretimi. İzmir: Tudem.

Temizyürek, F. (2003). Türkçe Öğretiminde Çocuk Edebiyatının Önemi. Türklük Bilimi Araştırmaları, $13(161-167)$. 
Uz Erşahin, I. (2009). Türkçe Ders Kitaplarında Yer Alan Çocuk Edebiyatı Metinlerinin Çağdaş Çocuk Edebiyatı İlkeleri Açısından Değerlendirilmesi ve Eğitsel Öneriler. Yayımlanmamış Yüksek Lisans Tezi. İstanbul Üniversitesi Sosyal Bilimler Enstitüsü, İstanbul.

Ülper, H. (2010). Okuma ve Anlamlandırma Becerilerinin Kazandırılması. Ankara: Nobel.

Yalçın, A. (2018). Son Bilimsel Gelişmeler Işığında Türkçenin Öğretimi Yöntemleri. Ankara: Akçă̆.

Yangın, B. (1998). Dinlediğini Anlama Becerisini Geliştirmede Elves Yönteminin Etkisi. Yayınlanmamış Doktora Tezi. Hacettepe Üniversitesi Sosyal Bilimler Enstitüsü, Ankara.

Zorbaz, K.Z. (2014). Yazma Eğitimi. M. Yılmaz (Ed.) içinde, Yeni Gelişmeler Işı̆̆ında Türkçe Öğretimi (ss. 109-147). Ankara: Pegem Akademi. 